\title{
New Measures of Chinese University Library Knowledge Service under the Cloudization Background
}

\author{
Jiayin Liu' ${ }^{1}$ Chen Chen ${ }^{2}$ \\ ${ }^{1}$ Library, Nanjing University of Aeronautics and Astronautics, Nanjing, China \\ ${ }^{2}$ Institute of Scientific and Technical Information, Nanjing University of Aeronautics and Astronautics, Nanjing, China \\ Email:ljylib@nuaa.edu.cn,chenchen_nuaa@163.com
}

How to cite this paper: Liu, J.Y. and Chen, C. (2018) New Measures of Chinese University Library Knowledge Service under the Cloudization Background. Intelligent Information Management, 10, 79-86. https://doi.org/10.4236/iim.2018.103006

Received: March 8, 2018

Accepted: May 11, 2018

Published: May 14, 2018

Copyright (c) 2018 by authors and Scientific Research Publishing Inc. This work is licensed under the Creative Commons Attribution International License (CC BY 4.0).

http://creativecommons.org/licenses/by/4.0/

\section{c) (i) Open Access}

\begin{abstract}
This article mainly explores and analyzes the application of network broadcast in the lecture service of university library under the cloudization background. By using the online survey method to investigate the lectures in some universities, it introduces the classification and characteristics of the network broadcast and obtains the advantage of network broadcast applied to lecture training through making contrast between the means of network multimedia. The result shows that the introduction of network broadcast can realize more customized, virtual and specialized lecture services, and facilitate the transformation of university library services in the digital era.
\end{abstract}

\section{Keywords}

University Library, Network Broadcast, Lecture Training, Information Services, Information Literacy

\section{Introduction}

University library is an important place for students to acquire knowledge, broaden their horizons, develop skills, improve their professional learning and lifelong learning ability, and is their "second classroom". The lecture service is an important part of education for university library users and also an important window for the communication between teachers and students. With the help of this way, it can change "passive service" into "active transmission", which can not only improve the readers' information literacy and promote library resources and services, but also can enhance the academic atmosphere of the library and attract more readers to promote the its development. 
Network broadcast is a new form of network media, which refers to that the scene produces and delivers information synchronously along with the occurrence, progress and process of certain event and has the information distribution method with two-way circulation process. At present, there are nearly 200 live platforms in China, with 200 million users and about 9 billion yuan of market size. The year of 2016 has become a truly "the first year of network broadcast". Network broadcast has become the most eye-catching "tuyere" in the Internet industry [1].

The university library has always been the leader and practitioner of new technology. Nowadays, the change of digital environment is redefining the status and function of the library and it is facing a new round of transformation and upgrading. Through the investigation and analysis of the present situation of university library lectures and combined with characteristic of network broadcast, the author discusses how to apply this novel way to lecture service and information literacy education.

\section{Present Situation of University Library Training Lectures}

\subsection{Related Research Review}

At present, there have been a lot of researches on the training lectures of university libraries. The author has carried out literature research and combed about the relevant literatures in recent three years, and roughly divides them into three categories.

The first category is the empirical study based on the present situation investigation. Though conducting a survey about the classification and main content of user training lecture of 12 university libraries at home, Han Li points out problems of university library user training lecture which exists in the aspects of publicity, content setting, lecture attendance, and acquisition of courseware, puts forward solutions according to the practice of training lectures and predicts the development trend of library user training lectures [2]. Frandsen and Tibyampansha explored how library training can promote electronic resource usage. The result shows that training sessions increase the usage of library e-resources significantly; however, the effect seems to be short-lived and training sessions alone may not increase the overall long-term usage [3].

The second category is applied research of innovative platform. Aiming at the existing problems, Chen Qin and Zhou Jianfang put forward that introduce micro-video technology to training to satisfy the users' demand of mobile learning and effectively improve their information literacy [4]. Zhou Yuxia and Xiong Ying selected 90 students and 3 teachers from two primary schools in Yunnan Province as research subjects. As for methodology, quantitative and qualitative methods were used. Results showed it was feasible to use Live Broadcast Classroom in solving the inequity problem in micro-level education: the gap between students' scores and attitudes towards English between urban and rural classes was narrowed [5]. Through Whatsapp search of mobile phone and web search, Chapu- 
tula, A.H surveys the use of Whatsapp, Facebook and other public platform in carrying out lectures and puts forward suggestions, such as scientific setting of lecture menu, the application of mass texting and interactional function in lecture survey, lecture reservation and establishment of group lecture platform and so on. The third category is to carry out the contrast research at home and abroad [6].

The third category is to carry out the contrast research at home and abroad. Hai Lan, Li Gang and others adopts web-based survey to collect the data of reader training lectures carried out at domestic and foreign university libraries, have analyzed its similarities and differences through comparison of its form and content, have expounded the characteristics of lectures and at last, have proposed suggestions towards university library about perfection of reader training lecture from the three aspects: satisfy information requirements of readers in different levels, expand the forms of reader training lecture and strengthen the teaching staff construction of training lecture [7].

Existing researches have made helpful discussions about various aspects of university library lectures from survey, application and comparison, which can be seen the importance of lecture service on university libraries. However, at present, there are few case analyses that introduce network broadcast, the form and content of library lecture change along with time, pay attention to explore its development mode and fit the reader demand, which is worthy of attention.

\subsection{Research about Some Universities}

At the beginning of the study, the author investigated the situation of some universities through webpage retrieval. It contains 985, 211 and general undergraduate level, which involves comprehensive, technical, agricultural, normal and artistic properties, and basically involves various colleges and universities. The results are shown in Table 1.

Table 1. Comparison of the present situation of some university lectures.

\begin{tabular}{|c|c|c|c|c|c|}
\hline School & Form of Lecture & Ways of Participation & $\begin{array}{c}\text { Time } \\
\text { Arrangement }\end{array}$ & Content of Lecture & $\begin{array}{c}\text { Ways of } \\
\text { Communication }\end{array}$ \\
\hline NJU & $\begin{array}{l}\text { On site/database vendor } \\
\text { remote training }\end{array}$ & On-site participation & Fixed & $\begin{array}{c}\text { Database/document } \\
\text { retrieval/artistic } \\
\text { appreciation }\end{array}$ & On-site communication \\
\hline SEU & $\begin{array}{l}\text { On site/database vendor } \\
\text { remote training }\end{array}$ & On-site participation & Fixed & $\begin{array}{l}\text { Database/thesis } \\
\text { writing/use of software }\end{array}$ & On-site communication \\
\hline NUAA & $\begin{array}{l}\text { On site/database vendor } \\
\text { remote training/micro lecture }\end{array}$ & $\begin{array}{l}\text { On-site participation/participation } \\
\text { on network the }\end{array}$ & Fixed & $\begin{array}{c}\text { Database/document } \\
\text { retrieval/use of } \\
\text { software/job application }\end{array}$ & $\begin{array}{c}\text { On-site } \\
\text { communication/online } \\
\text { communication }\end{array}$ \\
\hline $\mathrm{NNU}$ & $\begin{array}{l}\text { On site/database vendor } \\
\text { remote training }\end{array}$ & On-site participation & Fixed & $\begin{array}{c}\text { Database/thesis } \\
\text { writing/artistic } \\
\text { appreciation }\end{array}$ & On-site communication \\
\hline NAU & $\begin{array}{l}\text { On site/database vendor } \\
\text { remote training }\end{array}$ & On-site participation & Fixed & $\begin{array}{l}\text { Database/thesis } \\
\text { writing/artistic } \\
\text { appreciation }\end{array}$ & On-site communication \\
\hline NUA & On site & On-site participation & Fixed & $\begin{array}{c}\text { Artistic } \\
\text { appreciation/reading } \\
\text { guidance }\end{array}$ & On-site communication \\
\hline
\end{tabular}




\subsection{Analysis of Current Situation and Existing Problems}

\subsubsection{Single Form and Inconveniences in Participation}

According to the results of the survey, the lecture forms of the above six universities are mainly on-site lecture in the library and the remote online training of database vendors. Some schools have special lectures on specific subjects and specific levels of readers, but the fixed time and place have a high requirement on readers, and when the time is difficult to arrange, it is easy for readers to miss and difficult to make up.

\subsubsection{Single Form and Inconveniences in Participation}

According to several years of data statistics, the normal lectures of library are basically the same every year, with fewer famous special lectures. This is may the positioning of the library itself, but if there is no new idea, it is hard to attract readers in new era who have increasingly sharp taste and multiple channels of information acquisition. At the same time, there is limited time for answering and communicating on the on-site lecture, and many audiences with enthusiasm and problems fail to solve the problem on the spot and can't communicate further after the lecture.

\subsubsection{Lack of Publicity and Stuck in their University}

Through the author's investigation, we find that on the one hand, the publicity of lecture in each school is different, but generally it is weaker, and it in only limited to posters in libraries, grade QQ group transmission and WeChat official accounts push, which doesn't form better social publicity, and many readers even don't know the existence of lectures; on the other hand, the lecture communication among universities is limited, and meanwhile, it is difficult to basically cover the social people outside school who have information requirements. As a result, the number of lectures is small, but many readers who are in need are not satisfied.

\section{Network Broadcast Platform and Application Analysis}

\subsection{Classification and Characteristics of Live Broadcast Platforms}

From the classification of live broadcast channels, the platform mainly includes PC terminal and mobile terminal. There is no strict boundary between the two platforms, and both of them can be watched on their web pages or mobile terminals and show a trend of integrated development. The differences between the two platforms are mainly reflected in the way they are recommended to be watched, which also leads to huge differences in the main direction of the live broadcast platform, the type of anchors and the audience's preferences.

From the classification of main content, the platform can be divided into pan-entertainment broadcasting platform, whose main contents are games, online celebrities and outdoors, and vertical field broadcasting platform, whose main contents are education, finance and economics and sports. Pan-entertainment 
broadcasting platform is a kind of live broadcast platform with good development, mature business model and stable audience at present. However, the emerging vertical field broadcasting platform focuses on the single field, uses the long tail theory to capture the market segmentation and satisfies the certain needs of audience in entertainment, education and consulting.

In terms of communication characteristics, network broadcast has the characteristics of time fragmentation, instant interaction, bullet screen culture and quick sharing. Time fragmentation means that network broadcast can be watched in a fragmental time, without the need for the fixed time; instant interaction is similar to social software. The two-way real-time interaction of live streaming software is difficult for other words and video communication methods to match; as a subculture, bullet screen culture realizes the organic circulation of cultural production and consumption in network broadcast; quick sharing refers to the ability of the audience to share the broadcast to friends circle, micro blog and other social software easily by sending a link or QR code, the audience is accurate, and spread quickly.

\subsection{Comparative Analysis of Network Broadcast Platforms}

As mentioned above, the types and amount of network broadcast platform are various at present. Through the network investigation and contrast, the author has chosen six network broadcast platform with broad user base, relatively complete function and characteristics, including PC terminal and mobile terminal. Meanwhile, according to the requirements of library lectures, pay attention to understand live broadcast methods, communication channel, follow-up replay, auxiliary demonstration and other aspects, and make a judgment on the applicable types. The results are shown in Table 2 .

Table 2. Common network broadcast platform.

\begin{tabular}{|c|c|c|c|c|c|c|c|}
\hline $\begin{array}{c}\text { Live } \\
\text { Broadcast } \\
\text { Platform }\end{array}$ & $\begin{array}{l}\text { Live Broadcast } \\
\text { Method }\end{array}$ & $\begin{array}{l}\text { Communication } \\
\text { Channel }\end{array}$ & $\begin{array}{l}\text { Follow-up } \\
\text { Replay }\end{array}$ & $\begin{array}{c}\text { Auxiliary } \\
\text { Demonstration }\end{array}$ & Login Method & $\begin{array}{c}\text { Publicity } \\
\text { and } \\
\text { Sharing }\end{array}$ & $\begin{array}{c}\text { Applicable } \\
\text { Type }\end{array}$ \\
\hline Duoyu TV & Video & Bullet screen & Support & Support & Accounts/anonymity & Support & $\begin{array}{l}\text { Large-scale } \\
\text { lecture }\end{array}$ \\
\hline Panda TV & Video & Bullet screen & Support & Support & Accounts/anonymity & Support & $\begin{array}{l}\text { Large-scale } \\
\text { lecture }\end{array}$ \\
\hline $\begin{array}{c}\text { Live } \\
\text { broadcast of } \\
\text { Micro Blog }\end{array}$ & Video/word & Message/retransmission & Support & Nonsupport & Accounts/anonymity & Support & $\begin{array}{l}\text { Large-scale } \\
\text { lecture }\end{array}$ \\
\hline $\begin{array}{c}\text { Live } \\
\text { broadcast of } \\
\text { QQ Group }\end{array}$ & Video/audio/word & Group words/voice & Support & Support & Accounts & Support & $\begin{array}{l}\text { Sharing of } \\
\text { special topic }\end{array}$ \\
\hline $\begin{array}{c}\text { Live } \\
\text { broadcast of } \\
\text { WeChat } \\
\text { Group }\end{array}$ & Video/audio/word & Group words/ voice & Support & Nonsupport & Accounts & Support & $\begin{array}{l}\text { Sharing of } \\
\text { special topic }\end{array}$ \\
\hline
\end{tabular}




\subsection{Contrastive Analysis on the Application of Network Broadcast and Other Network Platforms}

Before the network broadcast rises, the university library has used wed-based multimedia to make a lot of beneficial explorations about their lecture forms, and among them, some prominent ways are: introduction of the database vendor training platform, the construction and use of MOOC platform and lecture resources sharing through FTP or network disk. Through survey, the author finds that although these methods have their own characteristics, they are not consistent with the objectives of the lecture activities in general, users have low enthusiasm in participation and the functional experience is unsatisfactory. The training platform of database vendors needs to register special accounts and wait for specific time, the lecture content is fixed, and various operations cannot meet the requirements of lecturers well; MOOC are more suitable for the study of professional courses but lack of real-time interactive experience of lectures; resource sharing can only show part of the lecture, and PPT or lecture notes are only a supplement to the speaker. In general, the existing functions of network broadcast platform are more suitable for the in-depth development of lecture training than other methods.

\section{Advantage Analysis on Application of Network Broadcast in Lecture Training}

\subsection{Reduce the Cost of Libraries and Readers}

Entity library lectures invite experts, arrange staff and prepare equipment and site, which will bring a series of economic cost, but if putting part of the lecture on the Internet, it only needs simple recording and camera equipment as well as network, which is very simple and convenient; at the same time, readers are free to choose time to tune in and watch and don't need to line up in advance. Make use of the fragmental time to study, which can reduce the time cost. Both sides get more information at a lower information cost and achieve a win-win situation.

\subsection{Break the Traditional Time and Territorial Restriction}

Traditional lectures have a high demand on time and place. Most of the lectures are in the daytime during the day, and many of the readers who are in need are in class, which is hard for them to attend the lecture while attending class; at the same time, it is difficult to arrange for the experts from foreign universities and other places, because of the journey and time. The form of online lectures cannot be limited by time and space, which extends the scope of lecturers to a certain extent; the ultimate benefit of this approach is the vast majority of readers, making them able to arrange their time freely and conveniently use various channels to listen to more abundant knowledge. In the end, it can realize the good environment and atmosphere of remote holding of library, remote speaking of lecturers and remote listening of reader. 


\subsection{Conveniently Subdivide Groups and Diversify Forms}

Traditional lectures label suitable people or majors, but most of the lectures are aimed at all readers, and there are fewer lecture contents for the minority and professional lecturers. Most of the lecturers are professionals and the chances for ordinary people to share knowledge and get on the platform are relatively small. However, the broadcasting cost of network broadcast is reduced and the convenience is greatly enhanced, which can satisfy the demands of more subdivision, make small groups fully share and communication and make individuals with professional knowledge and skill sharing willingness can give a lecture as a speaker. And the subdivision of audience and rise in the number of speakers make the lecture forms more diversified, and in the future, it can conduct outdoor field visits like practice base outside libraries and contrast and communication in public libraries, etc.

\subsection{Provide Free Exchange and Feedback Platform}

Network broadcast makes communication become timelier, and through message and bullet screens, readers can easily ask and communicate as well as can have the follow-up communication with speakers and other readers after the lecture, and even build a long-term relationship through social software. In terms of library, feedback of readers can be conveyed more timely and be improved continuously; for speakers, questions in past lectures have become real-time communication, which can be more closely related to the needs of the readers in lecture and control the situation in the process, and speakers themselves can also gain improvement.

\subsection{Expand Resource Reuse and Social Services}

There are usually lecture alliances among public libraries, sharing resources of each library and social organization, while most lectures of university library are only limited to their own school. The introduction of the network broadcast makes it very convenient for universities to share lecture resource with each other. The lecture in single school can benefit many universities through spread of social media. The screen recording and sound recording of network broadcast can be used repeatedly in different times, and compared with simple downloading of PPT, it is more comprehensive. The general trend of library development is to keep pace with social development, and modern libraries need to enhance the correlation with the society, participate in the process of social development and realize its own value from it. There exist various difficulties in the social open of university library at present, but network broadcast can benefit social person outside the school without increasing the operating costs of university libraries, which can be a window of social service for university library.

\section{Conclusion and Prospect}

Training lecture is a traditional and important part in the information service of 
university library, and introduce network broadcast to realize more customized, specialized and virtualized service, which also is one of methods for university library to indicate its social functions and professional value to digital age. The research scope of this paper is limited to Chinese universities, and only relevant suggestions are put forward. In subsequent research, practical activities need to be carried out. Although there are many details such as copyright of live broadcast and workflow system needing to be perfected in actual operation, no matter how to change, it is an eternal pursuit of library, a growing organism, to serve for readers and save their time.

\section{Acknowledgements}

This work was funded by the Project of Philosophy and Social Science of universities in Jiangsu Province (2014SJD051) and the Fundamental Research Funds for the Central Universities (NR2014048).

\section{References}

[1] iiMedia Research. Special Research on 2016 Chinese Live Broadcast Online Industry. http://www.iimedia.cn/42373.html

[2] Han, L. (2014) Analysis of Current Situation and Problems of User Training Lectures in University Libraries-Based on the Investigation of 12 University Libraries in China. Information Research, 6, 132-135.

[3] Frandsen, T.F., Tibyampansha, D., Ibrahim, G.R., et al. (2017) Library Training to Promote Electronic Resource Usage: A Case Study in Information Literacy Assessment. 6285.

[4] Chen, Q. and Zhou, J.F. (2016) Analysis on Application of Micro-Video in Training Lectures of University Library. Researches in Library Science, 4, 88-93.

[5] Zhou, Y.X. and Xiong, Y. (2017) Live Broadcast Classroom: A Feasible Solution for Chinese Rural Weak Education. International Journal of Distance Education Technologies, 15, 31-46. https://doi.org/10.4018/IJDET.2017070103

[6] Chaputula, A.H. and Mutula, S. (2018) Provision of Library and Information Services through Mobile Phones in Public University Libraries in Malawi. 2.

[7] Hai, L., Li, G., Zhang, H.Y. and Lu, M. (2014) Investigation and Analysis of Readers Training Lectures at Domestic and Foreign Universities Library. Library, 6, 85-88, 109. 